\title{
Transposition
}

Musique et Sciences Sociales

$1 \mid 2011$

Polyphonie et société

\section{Polyphonies, Bodies and Rhetoric of senses: latin chants in Corsica and the Pyrenees}

Jaume Ayats, Anna Costal, Iris Gayete and Joaquim Rabaseda

\section{OpenEdition}

\section{Journals}

Electronic version

URL: http://journals.openedition.org/transposition/139

DOI: 10.4000/transposition. 139

ISSN: $2110-6134$

Publisher

CRAL - Centre de recherche sur les arts et le langage

Electronic reference

Jaume Ayats, Anna Costal, Iris Gayete and Joaquim Rabaseda, «Polyphonies, Bodies and Rhetoric of senses: latin chants in Corsica and the Pyrenees », Transposition [Online], 1 | 2011, Online since 01 February 2011, connection on 19 April 2019. URL : http://journals.openedition.org/transposition/139 DOI : 10.4000/transposition. 139

This text was automatically generated on 19 April 2019

Licence Creative Commons

La revue Transposition est mise à disposition selon les termes de la Licence Creative Commons Attribution - Partage dans les Mêmes Conditions 4.0 International. 


\section{Polyphonies, Bodies and Rhetoric of senses: latin chants in Corsica and the Pyrenees}

Jaume Ayats, Anna Costal, Iris Gayete and Joaquim Rabaseda

\section{Multipart singing: rhetoric of the senses and the emotive construction of community}

1 The traditional activity of multipart singing by groups of men in the northwest Mediterranean has been well-observed and written about in recent years (see the synthesis of diverse regions in Ahmedaja \& Haidt 2008). Moreover, diverse monographs such as those by Macchiarella (2009) and Lortat-Jacob (1998), among others - show in detail the circumstances and ways in which the polyphonic chant is both a shared action and a personal experience that enables the individual to have a specific symbolic construction of the social group. The chanting activity is therefore placed in the centre of a masculine sociability that, at least until the first half of the 20th century, was an important part of the social organisation of villages. On diverse occasions, this activity surpasses the man's world and dialogue with that of women and children. But the question is the social importance of chanting. It transcends the limits of the religious consideration that it has been reduced to. Often it has been interpreted within a not futile attempt of wanting to distinguish between religious and secular, and without clarifying what the religiousness of the men who chant consists of.

2 The question we wish to tackle focuses on a very specific aspect of this rather complex activity. We can synthesise it in a question: what are the rhetorical procedures set into motion during this multipart singing? To put it another way: what are the rhetorical procedures that enable the emotion of the individual taking part to be built efficiently? Or even: what are the resources deployed to ensure the individual experiences that create the imagery of feeling part of the group? 
3 To sum up, we want to present a specific rhetoric of the senses that is activated with a series of highly coded ritual frameworks. The feeling of the individual encounters a path of development. It is due, precisely, to this rhetoric of the senses: from individual being, necessarily rooted in physical and sensitive aspects, the feeling of belonging to a social group is made possible. And by this, the group also exists.

Therefore, our approach to the polyphonic resources is made within a wider observation that includes the rhetoric of each sense. We believe that the sound ("musical" or "textual"), despite the privileged position it holds in social rituals, must be placed in a network alongside the other rhetorical forms: sight, touch, smell and even taste. In some way, the rhetoric of the body and the senses built a specific communitas (to follow Turner's classical notion, 1969). When the actors are involved by the singing, they transform their disposition and state. Then, the musical interest and polyphonic construction are nothing more (and nothing less!) than one of the decisive elements. Moreover, in the cases that we expose, the component of entry into a special time and a certain consideration of sacredness are perceptible. That refutes more and more an exclusivity of the sound.

5 To our understanding, a set of specific catholic rituals, without wishing to force the meaning, have or had a component of rite of passage. The idea we introduce starts from this fabric of feelings that are structured and make sense within this temporary nature.

The two rituals that we have chosen to present this rhetorical process are the Ceremony of Tenebrae on Holy Wednesday which the Cunfraternita di Sant'Antone Abbate (Brotherhood of Saint Anthony the Abbot) from Calvi carry out in Corsica, and the Ceremony of Vespers that was chanted in the Catalan Pyrenees after lunch on the days of the main festivals of the year. We will complement these two religious festivals with other details from the rituals of Holy Week both in Calvi and the Pyrenees. We are moving within a notably similar cultural area as regards the development of these rituals: they are religious multipart singing in Latin and done by men, where the polyphonic construction is not considered indispensable, but an embellishment of the chant. In both situations the chants have or had an equivalent and a very interesting contrast with multipart singing in the tavern, as can still be seen today with the Corsican paghjella chant, despite the intense process of folklorization and heritage preservation it has experienced.

7 It should be pointed out, however, that the research in Calvi is the result of a direct observation (Holy Week in 2008 and 2010) whereas access to the activity of Vespers in the Pyrenees is based on interviews with the participants, but between thirty and fifty years after the activity was no longer done (you can see the details in Ayats, Costal and Gayete 2010).

\section{The entrance into silence and emotion: the Ceremony of Holy Wednesday in Calvi}

8 A catholic religious brotherhood in the 21th century? It would be relatively easy to present the brotherhood of Sant'Antone Abbate, placing it in the past, in the localisation of its Oratoriu (oratory) within the fortified Citatella (citadel) of Calvi, ${ }^{1}$ on its 14 th-century origin and on the activities focused on the Holy Week acts, with an undeniable picturesque and tourism-oriented aspect. However, the current reality is much more 
complex and has many other facets. This brotherhood, along with the brotherhood of Sant'Eramu (Saint Erasmus, patron saint of seamen and fishermen of the low town of Calvi) has a special relevance today in the life of the small tourist resort and military town of Calvi. Beneath the image of continuing the tradition of a brotherhood for centuries, the activity undertaken establishes a constant tension between different social sectors and between apparently contradictory discourses. The institutional Church of the last decades has observed the brotherhood from the point of view of complicity and, at the same time, with certain distrust, probably due to the religious anti-establishment movement that the brotherhood has always represented. Some of the French left calls them conservatives and traditionalists because they are a catholic group and they chant in Latin. A section of the French right is suspicious of them for not accepting republican values because they consider that demanding a Corsican identity does not undermine France. And within the brotherhood in reality there are a variety of quite distinct sensibilities, but which come together in a set of basic principles: mutual support and charitable social support - in a part of clear Franciscan resonances -, and by the other hand the construction of a common identity and identity of a town in a very sparsely populated area. Everything is based on personal and direct exchange. What value do the chants and rituals we are going to study have? Are they anachronistic fossils? We must start from the reality that the value of the musical aim of the study becomes meaningless if we do not take into account the whole set of social factors.

Are they Neo-Gramscians or alternative thinkers? Conservatives or progressives? Corsicans or French? Franciscans or traditionalists? The young members, who join when they are twelve or thirteen, have one thing clear: the brotherhood is a tradition and, for that very reason, they consider it an alternative to the dominant social currents that they do not want to accept without doing anything. The priore (prior) and the guvernatore (governor) - the two main positions - constantly recycle chants and rituals of the past. They know that today these chants and rituals have different meanings and values from those that they had a few decades ago. They have new conceptions of what "the tradition" is and of the role that a brotherhood may have, and they are in a conflict in permanent tension in the search for a negotiated social space. For them, this is part of the tradition. To a greater or lesser extent, it can probably be considered that the brotherhood members act within a will to resist to the types of individualisation to which the majority of social forces compel them. In that sense, they do not renounce the political activity and the Corsican language as a language of common use within the institution.

10 Being a brotherhood member may be linked to the family or the social setting. The members of Cunfraternita are one hundred in number and of all ages. Every year young people join it. In general, the young ones come from social and educational activism of the officers that govern the brotherhood. They underline the importance of the religious and traditional experience for them: "teaching the chants to future generations and perpetuating the brotherhood from generation to generation", states a boy of just under twenty, adding immediately "the religious aspect is the tradition, the chant", finishing by stressing "without the chant, this would be very different". The majority of the most active brotherhood members (about twenty) attend enthusiastically above all for the act of chanting and for the ritual. They hardly ever rehearse, but they learn to chant by listening to the others, whether during the acts or also in the bar, testing voices amid 
paghjella chants and other anecdotes. When they feel confident and ready, they begin to chant the rituals.

11 The other important aspect involved in the task of a brotherhood member that many mention "is to accompany the dead, accompany the family of the deceased", chanting at all the funerals in the town and accompanying the deceased to the cemetery.

The two brotherhoods work very hard between Holy Wednesday and Easter Monday. During Lent they carry out the via crucis (stations) inside the oratory every Sunday. The Palm Sunday mass and the via crucis of that afternoon represent the end of the preparatory period, of waiting for Holy Week. Within the acts of Holy Week, Wednesday is the first important day for the brotherhood members: the Matins and Lauds called "Tenebrae"2 open the special space, a "time outside time" (Turner 2009).

After working and having lunch, the prior and another brotherhood members go to pick rosemary on the cliffs of the western coast of Calvi. Amidst the praises for the fine aroma and excellent flowering state of the plant, they explain that they only pick within the municipal boundaries of Calvi. The idea of a Calvian identity governs each and every ritual of the brotherhood. With the rosemary, a group of brotherhood members make a bed of plants on earth, before the altar, for the image of crucified Christ who will be the focus of all the praying that afternoon. At 6 p.m., with everything ready, they ring the bell and the other brothers and sisters of the Annunciation ${ }^{3}$ gradually arrive, as well as other attendees (a very small number of interested people and the occasional passing tourist). They turn off the electric lights and the oratory is lit only by candles and especially by a large triangular candelabrum with fifteen candles, located in the centre of the nave. According to the liturgical indications, in each psalm a young brotherhood member will put out a couple of candles of the candelabra.

At the beginning of the Ceremony of Calvi the brotherhood members are seated opposite each other on benches oriented according to the length of the nave (facing side to side between the lateral columns that go from the altar to the entrance), leaving a large space between them. The governor - the second post of the brotherhood - sings the antiphon of the first psalm from the benches of one side. In the intonation of the governor, the whole group on the opposite bench (with the prior) respond, and here begins the constant alternation between the two sections of brotherhood members, about ten on each side, who develop the whole psalm verse by verse until the final antiphon, also alternating. They chant the antiphon standing to continue seated once the psalm has been started; finally, on the resumption of the antiphon, they stand up again. In the psalms, the brotherhood members chant a unique and simple melody of recitation, endeavouring to join together in the syllable division, within a flexible temporary distribution, where the number of syllables and accentual supports constitute the internal grammar when enunciating each verse. The voice of the prior and the governor stand out from the whole. The voices begin more doubtfully, and gradually join together in an increasingly more consolidated melodic part. The intervals of the melody are slightly small, the third major being very clear, and which is often situated between the third major and third minor.

Between the psalms of Matins and those of Lauds, the governor addresses the lectern situated in front of the large candelabra, in the middle of the nave facing the altar, and begins the first lesson of the Lamentatio Ieremiae Prophetae. It was expected. And here the relationship between soloist and group takes on a new shape: the soloist utters, calmly and carefully, the text of the verses, and all the others punctuate them with a brief 
polyphonic intervention that occupies the place of each of the Hebrew letters that the verses distribute. The final response of the lesson also involves alternation between soloist and group. The feeling that the brotherhood members mention afterwards is that at this moment they enter into a different emotional state. The prior of Sant'Eramu and later the prior of Sant'Antone follow the governor in the place of soloist in the two other parts of the Lamentatio Ieremiae. They are the main posts of authority of an institution overlooked by the signs "Silenzio" (silence) and "Obedienza" (obedience) on the columns.

On ending the psalms, a movement occurs amongst all the brotherhood members. They stand before the altar, in a semicircle looking at Christ. And there the prior intones the Benedictus or Chant of Zacharias, a psalm (with initial and final antiphon) that is of great importance as the culmination of the Lauds. All the brotherhood members know that it is the time for the polyphonic explosion of voices, when the volume and expressiveness of the voices will enter into a maximum level, and the rivucate or ornamentations with the voice will be inevitable. The prior of Sant'Antone indicates with discrete gestures the role of the soloist of each strophe, which he entrusts to the best voices, and which will be answered with the emphatic response of the group, elbow to elbow, closed in their maximum complicity.

At the end of the Benedictus the brotherhood member in charge of the candelabra will pick up the candle from the top, the only one remaining lit, and will carry it behind the altar. At that moment, with the brotherhood members in a circle kneeling before Christ reclining over the rosemary, they sing 0 mio Signore amato, a chant in Italian - the only one that is not in Latin - appropriate for Holy Week, and which will be repeated dozens of times in the processions of Thursday and Good Friday, always before the sepulchres of Christ. Just on finishing, the deafening din explodes of the two rattles that the prior and the governor grip. The act finishes with silence.

The entrance of darkness and the racket of the rattles aim to relive the evangelical episode of the death of Jesus Christ, which caused the sunlight to be filled with darkness at midday and an earthquake that tore the curtains from the temple. ${ }^{4}$ The order of the oration is, therefore, a synthesis of the regular order of the Matins and the Lauds, following the ritual that in the same place they also chant on the novena (novenary) preceding All Saints Day. The psalms, however, are today separated by three lessons special to this day, and which take on an important symbolic role: it is part of the nine Lamentatio Ieremiae Prophetae.

19 Afternoon prayer on Wednesday afternoon is the first act where the brotherhood members who lead the main liturgical and processional acts of the week meet, until the procession of Easter Monday after the mass, with the procession of blessing of the township with the Virgin. The participation of the sisters will also be important, with the support they provide throughout the rituals, both in terms of work and logistics and symbolically. This is why this Wednesday afternoon assumes the role of the commencement, of entering into a state of spirit and a dedication of effort and time towards a single objective for almost five days. It is the moment of meeting and formation of the group. Moreover, this emotive construction and sense of being and doing together is achieved above all through the sonorous elaboration, the correct use of the voices, the noise and the silence, but also assisted by the space, the smell and the darkness of the ritual of the Tenebrae. 


\section{The memory of when "the walls of the church shook": Vespers of the Catalan Pyrenees} twelve and fifteen big annual festivals that represented an important break in the monotony of daily life. Music and chants always had a very relevant role in the celebrations, ${ }^{5}$ and particularly in the three religious celebrations: Compline the day before the festival, the main mass and Vespers. In the years of the Second Republic (1931-1939) religious attendance decreased, but took off in the post-war period until the abandonment of Compline and, after the II Vatican Council, Vespers (Ayats, Costal, Gayete, 2010). In very few villages in the county of Pallars Sobirà, Vespers continued to be chanted for some decades, and the final chant, the Magnificat, has continued to be chanted in exceptional moments until even today. The Vespers have left a very vital and real memory that has enabled a detailed narration of all the elements that met, as well as the chants and polyphonic behaviours.

Only men sang them from the upper gallery or choir ${ }^{6}$ of the church, an exclusively male space in contrast with the almost exclusively women's and children's space of the ground floor of the church. The leading players of the act were the cantadors, ${ }^{7}$ who had the exclusivity of being able to perform the liturgical chants in Latin (together with or alternating with the priest), in the way of chants around the lectern (Pérès and Cheyronnaud 2001) but with a very substantial difference: they were not paid specialists, but represented the main homes of the village. Being recognised as a cantador in this circumstance did not only refer to singing, but signified a recognition of social leadership that not everyone could assume, and was shown by having their own place on the row of seats of the choir they belonged to. Broadly, we can say that the cantadors were the heads of house and were generally of a mature age. It should be noted that the villages in the Pallars county are organised by houses, in other words by units of home and production. The houses cooperated in the life of the village in conditions of some equality - despite the fact that some were richer and others more modest - and were co-owners of large communal grazing lands that supported a major part of the mountain economy. In principle, they state in all the villages, everybody could be a cantador, but the men who did not represent any house, such as salaried workers or new arrivals - married to a young woman from the village - found it difficult to ever reach the category of cantador, irrespective of their ability to sing. From adolescence, the young men went to the top of the choir and began learning to sing, but would only become cantador with the passing of time and succeeding someone who had passed away. In the Pyrenees no-one recalls whether the cantadors had ever formed part of a religious brotherhood.

In the ritual of the Vespers the five perceptive psalms succeeded each other with the corresponding antiphons, as well as the hymn, always with the cantadors divided into two halves that alternated in the chant of each verse. In some villages, each head of house had the authority of being able to start the intonation of the first verse of a specific psalm: he possessed a type of ownership and it was a moment for showing it before the whole village. The Vespers ended with the solemn and emblematic chant of the Magnificat, dedicated to the Virgin Mary, a chant which in many villages was repeated twice. Everyone remembers the first psalms with less volume and a progressive increase of the polyphonic density and the appearance of the voices to culminate with the awaited chant

Transposition, 1 | 2011 
of the Magnificat (the equivalent of the Benedictus) where the vocal explosion was at its zenith. After chanting it with the priest over the cor, the choir, the cantadors repeated it alone and with even more intensity while the priest censed the altar. Thus some people exclaim that with the Magnificat, "the walls of the church thundered!" or even "shook". The strength and emotion of this final moment is repeatedly remembered and narrated by all the interviewees, and the women - who listened from the ground floor of the church - remember the tunes and how they discerned the voice of each cantador and appraised the performance. The chant was an important moment in the construction of the social image and perception of the relationships of power, gender and social geography of the village (Ayats, Costal and Gayete 2010).

The descriptions of the Vespers in the Pyrenees by old cantadors and other attendees have provided us with details surprisingly similar to the Ceremony of Calvi and with a commonly shared element: the increase in the level of sound throughout the act, and especially the increase of the polyphony.

\section{In search of sonorous fullness}

Multipart singing is one of the ways of constructing what we could call the rhetoric of sonorous fullness, a search for the growing density of the sonorous effect that guides the development of both acts. With which elements and aesthetic criteria is this done? It is here where we observe that the construction in voices cannot be unconnected from the other vocal and acoustic procedures that contribute to the increase in the sonorous effect.

The Ceremony of Calvi begins with the monodic chant of a single melody for the psalms. It is a melody that the brotherhood members reencounter after months of not chanting it (remember that they have not rehearsed it previously), and that they utter in a hardly perceptible voice and with difficulty in fitting in the syllables of each verse of the psalm, which always change in number. The prior and the governor must hold the chant together with more vocal presence in order to give continuity to a simple and littleornamented scansion. After the three psalms of Matins, with the three lessons of Jeremiah, the leaders take the role of soloist and endeavour to create the sound that incites the response of the group with their chant. In the personal expression of the soloist one clearly perceives the desire to transmit and share emotion: the voice produces melismas or rivucate at the end of each verse and, even more, opens out in expressiveness in the word Iaerusalem. The polyphony of the Hebrew letters - aleph, beit, gímmel, dalet, etc. - which the group enunciates as a response, is increasingly more solid and sonorous, with the use of rivucate that each cantore 8 elaborates with more and more temporal freedom, creating a heterophonic sonority, which fills the whole space. Let's look at a schematic notation of each of the parts: 


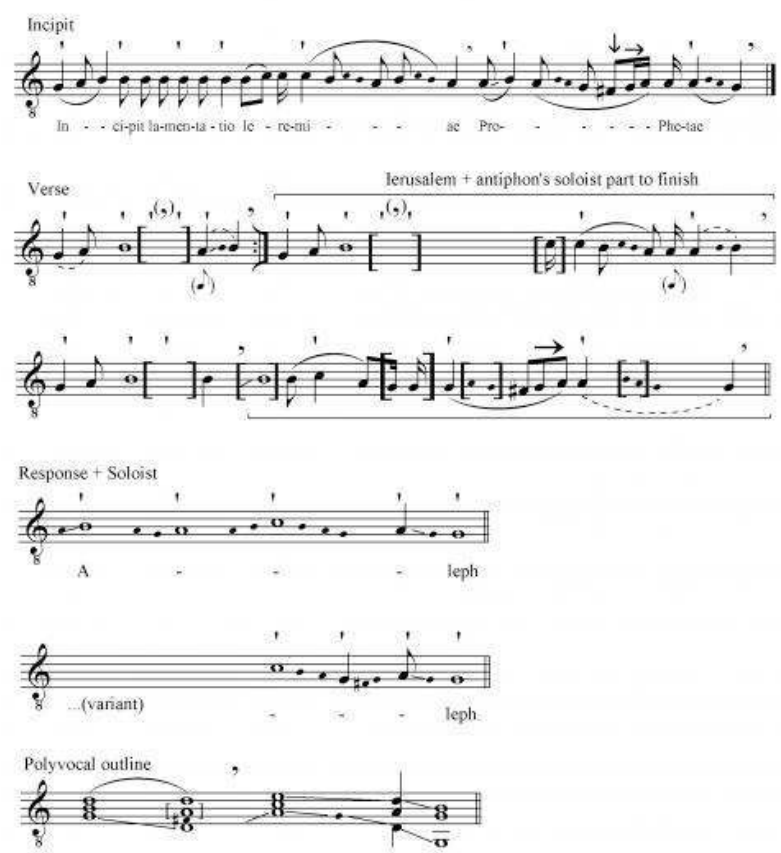

We place the melodic elements that only appear occasionally between square brackets. Of interest is the $\mathrm{F \#} \mathrm{degree} \mathrm{of} \mathrm{the} \mathrm{second} \mathrm{chord} \mathrm{of} \mathrm{the} \mathrm{response} \mathrm{(Hebrew} \mathrm{letters):} \mathrm{it} \mathrm{is} \mathrm{only}$ performed a couple of times, thus a little-used possibility. However, this detail shows that the part of the low voice (bassu) allows for more than one possibility, which the cantadors may use or not.

The psalms of Lauds follow the same procedure as that of Matins, but now with an important novelty: over the central melodic part of the voices one begins to sense a higher part (a third higher parallel) and attempts at a lower voice that seeks, with certain freedom, the modal support. The vast majority of brotherhood members chant the main melody, and only one is allowed to chant the high or low voice, in a clearly inferior volume. In contrast with the first psalms, one now perceives a certain demonstration of the individuality of the cantadors: those that decide to chant the higher or lower voice in relation to the central melody, and a slightly greater freedom to elaborate some rivucate. Let's see a synthetic outline:

\section{The psalm's voices}

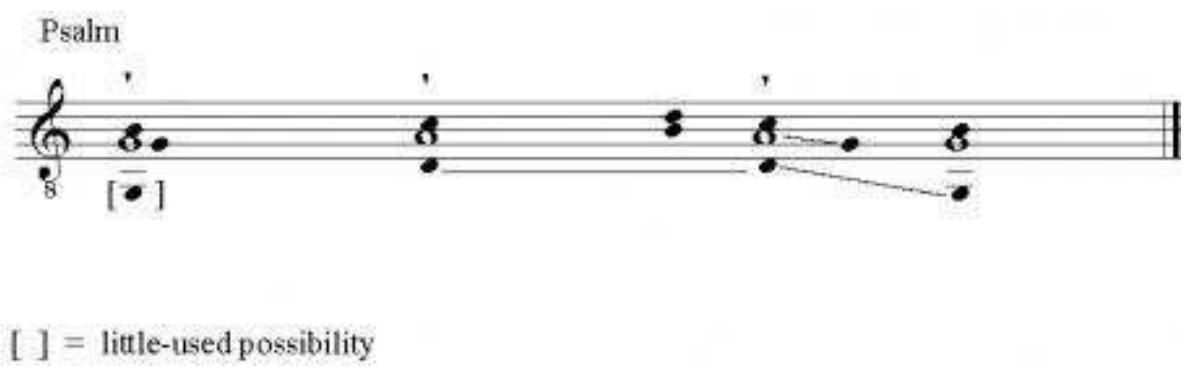

28 In the Benedictus the recitative chord of the psalm is clearly transformed into multipart singing. The timbre of each brotherhood member takes hold in search of singularity, and 
the arrangement in semicircle, standing around the reclining Christ, also transforms the sonority. The whole is created by the sum of underlined individualities, and does not become the fusion of a single and indistinct voice. The polyvocality is nothing more than the search for this same effect of individuals gathered in their singularity to create a whole. The volume is at a maximum in the response the group makes to each soloist. The soloists may have the help - it appears completely spontaneously - of one other cantore at the most, who intones an extremely discrete higher third, almost only suggested (and which here follows the main melody very strictly in parallel thirds), and which hardly articulates the text. It has been months since they have chanted the Benedictus and the brotherhood members have awaited it.

We provide a schematic notation of the melody that the whole group chant, the melody of the soloist and of the polyphonic arrangement of the group, all with a common melodic profile. The duration values are merely illustrative, within the recitative flexibility. According to the number of syllables of the verse, some melodic elements can be activated or not. We have endeavoured to establish the main elements of variability between square brackets.

Benedictus

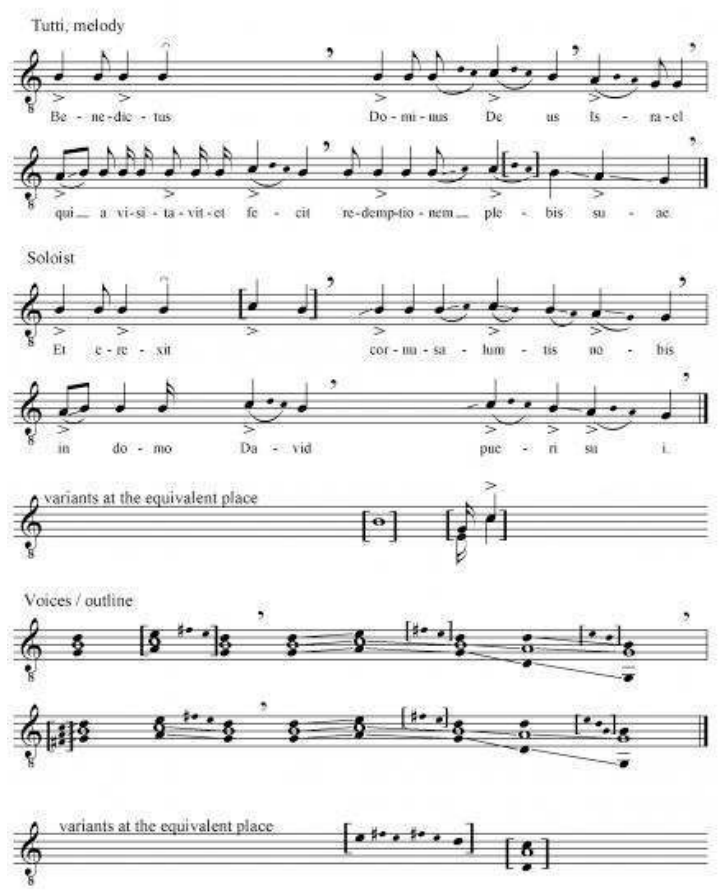

After the chant, and in total silence, the young brotherhood member moves the last candle to behind the altar while all the brotherhood members are kneeling. The prior of Sant'Antone Abbate intones the final chant, the central chant of the entire Holy Week, 0 mio Signore amato. It is in Italian, and the cantadors understand precisely the words of asking for forgiveness, in contrast to the distance and little understanding they have of the texts in Latin:

O loved Lord of mine,

My most valued Good, my God,

Pardon this all contrite heart of mine. 


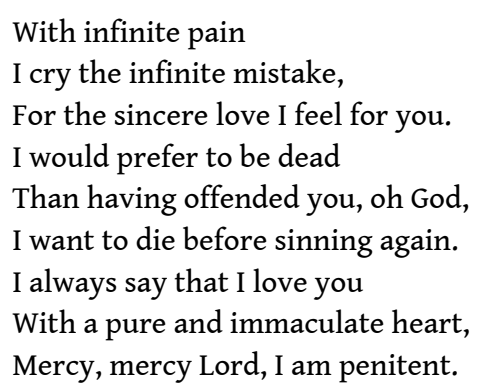

It is the sonorous entrance into the special space of sorrow and feeling of these days. It is therefore much-awaited. Right at the start one can notice a change in the timbre of the voices, which becomes rough and hard. They also employ generous rivucate and an explosive polyphony of three voices: the group repeats in voice each phrase that the soloist prior has just formulated, with an interesting pass of the minor chord of the beginning to the major chord of the ending. It is another demonstration of vocal individualities, that is also perceived in the flexibility of rhythmic articulation, above all that of the soloist, and which come together to form a potent whole. The most highpitched and the lowest voice are chanted by a few brotherhood members, while the majority chants the melody. In the close-on three minutes that the two strophes last, the attendees have a great sensation of sonorous fullness and it seems that this sensation is felt even more strongly by the cantori.

We note a melodic outline, including a certain number of variants. For the rhythm, we have chosen to establish two margins of production: from the beat quite close to dotted crotchet (always scanned, however, with certain flexibility) and the interpretations that shorten specific syllables and strengthen the expressiveness or emphasis (noted over the pentagram).

\section{O mio Signore amato}

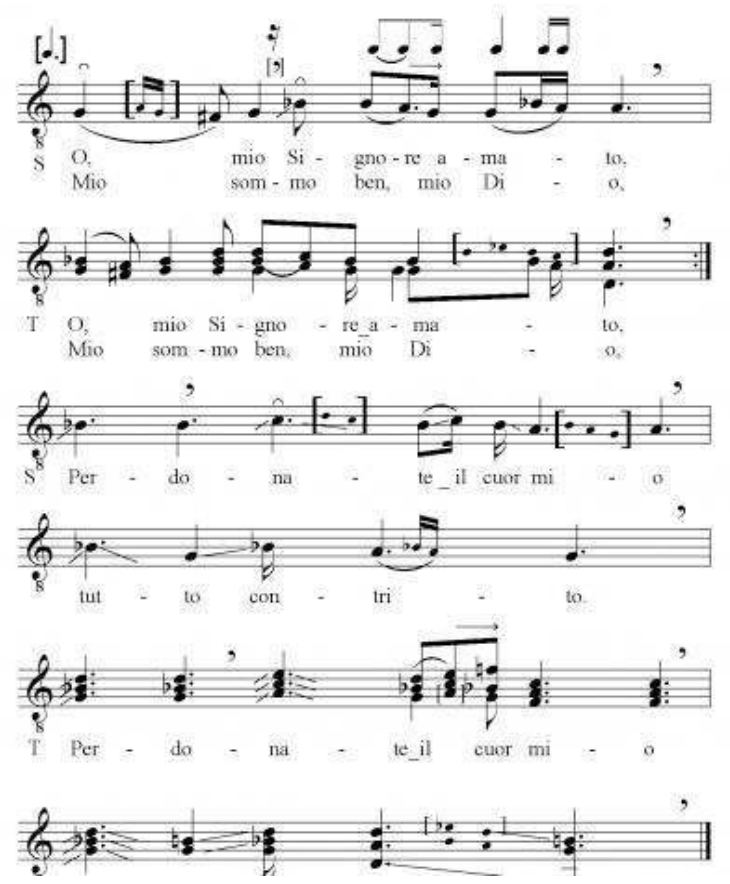

Just after the final explosion of the 0 mio Signore amato, the prior recites a brief oration and then the two priors make the deafening sound of the rattles resound, hitting the iron 
with the wood to the ground (in a movement that is horizontal and vertical at the same time). They are a few seconds of maximum noise, of sonorous saturation that fills the space of the oratory, in the utmost darkness. Then, just three seconds of murmured prayer by the prior are followed by the Amen, also murmured, as response. Silence behind. The act has finished, and only after a few seconds, with the brotherhood members abandoning the central circle, do the sounds of words slowly begin to awaken.

In the Vespers of the Pyrenees we see an increasing similarity of the polyphonic density and of the freedom of each cantador to make more ornamentation and employ a more individualised timbre. And not only in the descriptions remembered from decades ago. In a meeting we organised of cantadors from diverse villages to record the chants, at the moment of the Magnificat the sonorous intensity rose perceptibly. And in the final part of this chant (Gloria), some cantadors employed melodic variants and ornamentations up to a point where the priest, who acted as "specialist", criticised some of them as being excessive. It approaches, without doubt, this effect of making the church thunder. However, in contrast, the polyphonic effect is not essential for the development of the chants.

In the conception that the cantadors have of the Vespers, each psalm and the Magnificat have a melody called chant or voice. For them, it is enough to chant this melody so that the ritual is correct. However, when there are a certain number, some of the leading cantadors may undertake a higher or lower part of the chant (l'alt and el baix, the high and the low voice), in an individual behaviour that they describe with the words escapar-se, distingir-se or presumir (escape, distinguish or show off). Let's look at the parts of the Magnificat schematically:

\section{Magnificat}

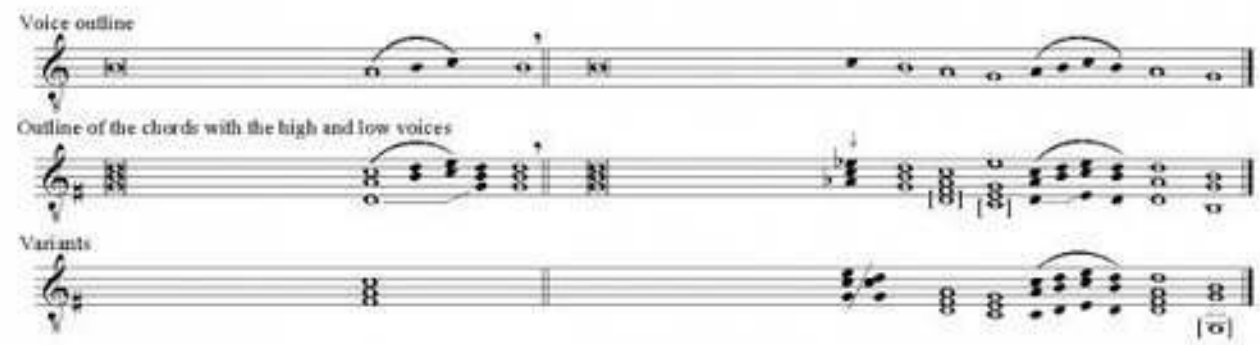

In both Corsica and the Pyrenees we observe the same conception: an essential main melody that may be complemented (as a way of embellishment or ornamentation) with a higher-pitched part and a lower part. While the majority of cantadors confine themselves to the main melody, only one (or some, in Corsica) can be bold enough to formulate the high-pitched part, which is well defined, or a low part, which may take on diverse concretions, with much more freedom of whoever chants it. Nevertheless, the cantadors do not conceive each part as different things, but they confirm without doubting that they are chanting the same. There is not, then, the polyphonic conception that we often imagine from an academic viewpoint, but that the parallel nature of the voices could be considered as a specific possibility of heterophony. Petru Bertoni, the prior of Sant'Antone, states it clearly:

We sing the chant of the mass in three voices: bass, second (the main one) and third. If we are unable to do it, we chant the second and the bass; and if not that, the second and the 
third. And if we are only able to chant in one voice, the second. For the mass of all saints and for the big festivals we always chant in three voices. In the processions we do not chant the bass voice because it cannot be heard: everyone chants the second and some the third. When we go under a vault or a narrower spot, then we do all three voices! It is a bit like how one feels at any given moment. [...] is much reduced; melodies and sharp part that move in ranges of between a third and a sixth, and a little broader (of eighth or ninth) for the low part. These much-shared ranges show us another characteristic of the chant: it is always expressed within an enormously comfortable and controlled register that enables the cantador, however entered they are, a very well-determined timbric projection and movement of the voice, always by joint degrees. Without the need for anyone to determine the tone of the section, the corporal perception of the soloists themselves places the melody within a very narrow margin of register, with little variability. During the processions tiredness can indeed set in, with a lowering of intonation; or, sometimes, the particular emotion of a moment, with a rise. The "sonorous body" of the cantadors is, therefore, very trained for specific registers, for a very specific timbre and expressive strength, the purpose of which is the sonorous fullness that we described as a result. Petru Bertoni also puts it into words when he says:

The young men chant with a head voice [with little intensity]. They must chant loudly, and they need their lungs, all their body and not just the neck. The body is important like a guitar. Everyone must be in a situation to chant. In Corsica the young men wish and try to sing like artists, they want to sing like them. Brotherhood members, however, are not 'cantaori' [in the sense of the artist], but 'cantori'.

41

We believe that another important aspect is the acoustic response of the space where it is chanted. The oratory of Sant'Antone, built around 1510 and reformed in the second half of the 19th century, contributes to the sought-after effect of sonorous fullness. Despite having lost the old benches and wooden daises the space has a particular architecture. The columns, in plaster and wood with the interior hollow, support a false vault, of the same materials, that leaves a notable empty space as far as the real roof of the building. The acoustic result is that one can hear distinctly and very easily the first harmonics of the sound emitted. When only a soloist chants, the high octave of his chant is perceived with a great deal of sharpness. When the whole group chants in unison, one immediately has the sensation that someone intones the high octave. When the chant is polyphonic, adding the diverse timbres, the effect of the harmonics is much more powerful, creating the sensation of a compressed space of voices and resonance. We have perceived this same effect in diverse churches in the Pyrenees, and it fully corresponds to the 
description that the cantadors give when they say that the church must thunder, and when they state that if the low part finds the exact spot of intonation and "compresses it", the thunderous effect is maximum. The wooden daises and the arrangement of the rows of seats right at the end of the nave vaulting, as we understand it, have helped as an acoustic element of amplifying sound and, in particular, amplifying the harmonics.

A brief review of the chords helps us understand better the sought-after harmonic effect. In the following outline the chords of the four polyphonies observed in Calvi are symbolised: in the Psalms, the Lamentatio and the Benedictus, the chords are reduced to four possibilities (apart from two more that we understand as passing movements). Only in the final chant, the main chord in minor seems to carry a substantial difference. However, for purposes of chord intervals, as we show below, two of the three different chords that 0 mio Signore amato demonstrates correspond to chord arrangements of the preceding polyphonies, and the third chord can be understood as a passing movement. They correspond in full to the chords of the Catalan Magnificat. Therefore, the basic chords are reduced to the four that we note down in the pentagram of synthesis. ${ }^{9}$

\section{Chords}
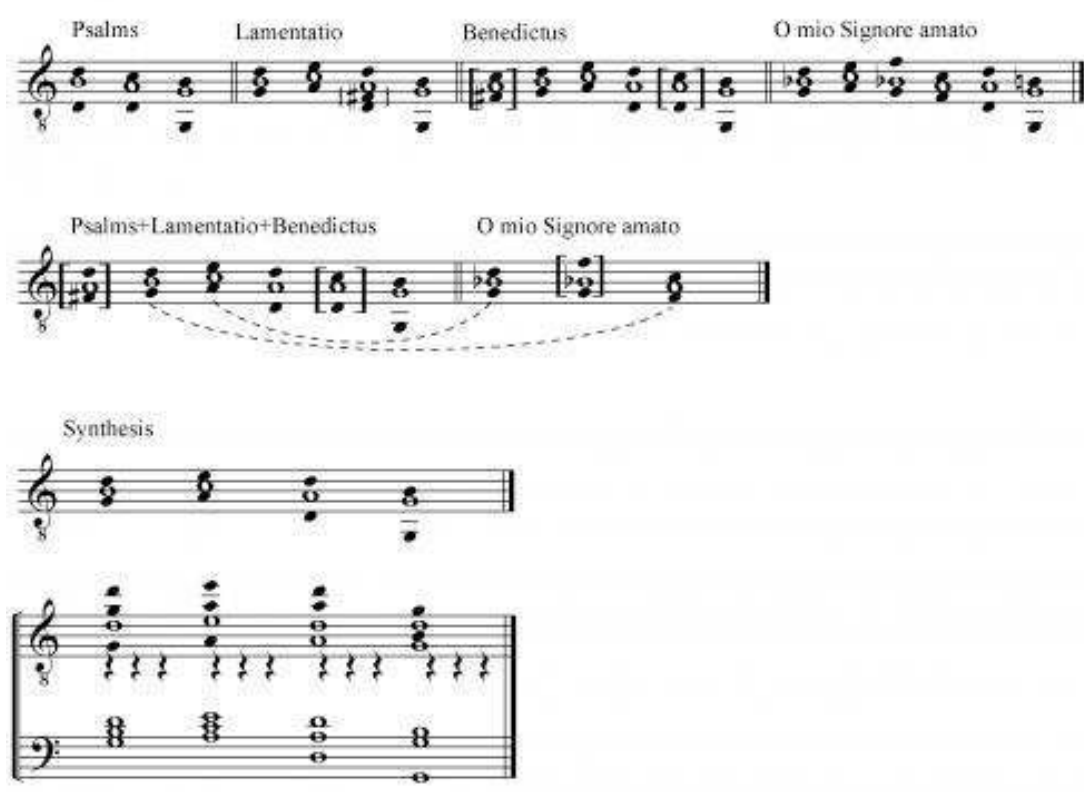

The arrangement of the higher and lower voices around the melody can be described by means of three possibilities, which are greatly shared - with some variants - in the Western Mediterranean countries: - strict parallelism with the melody, producing higher and lower thirds (with the result of the surprising harmonically sonorous consecutive parallel fifths); - small areas of drone of a voice (the higher or the lower) in the dominant or fifth degree of the mode (the higher voice is the clearest moment in the Lamentatio); it is the one that in other works we have called "moving drone" (Ayats and Martínez 2008); - the cadential opening of the two last chords, with the chord without thirds and duplicating the fifth degree of the scale (re-la-re') and the final chord, with the duplication of the first degree, along with the third higher major. 
As a whole, this effect of harmonic fullness, of movements and timbric exuberance of the voices is provided: a full aesthetic in the construction of the ideal of group chant, but which cannot remain unconnected to other corporal perceptions.

\section{The other rhetoric of the senses}

Indeed, we cannot understand the rhetoric of sonorous construction during the ritual act without taking into account the other corporal senses. If we pay attention to the descriptions they give us of the Vespers in the Catalan Pyrenees, we come across revealing aspects in this sense. The cantadors in the gallery standing on a higher floor and open to the church nave, right at the opposite end to the altar. The east-west position of nearly all the churches in the area and the time of the ceremony (after lunch, but earlier or later depending on the season) make us realise that the rose window over the heads of the cantadors greatly illuminated the space of the choir, whenever it was a clear day. This had a positive effect for reading the texts on the big lectern. It also had the effect of increasing the strength of the ritual: as the Vespers progressed, the sun had a more direct bearing on the rose window and, above all, from below, the choir was lit up and from there the church nave. We should remember that we are dealing with churches that are very often dark and minimally illuminated. The increase in the sonorous density went in consonance with the sensation of the increase in light (conditioned by the time of year, but particularly efficient and of a golden tone in winter, which is when half of the annual festivals we have been told about are concentrated). It was an increase in sonorous and luminous tension that culminated with the repetition of the Magnificat with the priest censing the whole altar and the gilds of the altarpiece in churches, which in general were totally painted: it is this moment that everyone remembers and that all those interviewed recall with enthusiasm. The sonorous, luminous and olfactory construction as a whole creates the appropriate rhetoric so that one notes that "the walls of the church shudder".

Furthermore, diverse interviews in the Pyrenees recall the childhood memory of the old men who after the big lunch on the festive day climbed up the steps to the choir dispersing an intense smell of wine, different alcoholic drinks, coffee and cigars. The aroma of the festival was inseparable from the aroma that expanded in the Vespers until the final incense, and very distinct from the intense daily aromas of the animals. Perhaps this smell-taste link may seem anecdotic. However, we have quite a few indications that support this hypothesis. The accounts of those interviewed reiterate an exact memory of the corporal closeness and the smells, even though this does not lead to an aesthetic reflection.

In Calvi, the religious spaces of Holy Week have two unquestionable aromas: the aroma of rosemary which is common on all the deathbeds of Christ and the aroma of the canistrelli, the ring-shaped cake that is blessed on Maundy Thursday in memory of the last supper and which the prior of the brotherhood shares out personally among all the brotherhood members (and which everyone eats immediately, some beginning once inside the oratory or in the bar itself). These two aromas place the memory of these days, as Petru Bertoni states:

They are plants that have a very strong smell. They recall the old aromatic plants that rather embittered the stink of death. It is ritual. In all the sepulchres of Christ there is only this. Chanting is a culture: there is the smell of rosemary and the canistrelli, and all mixed together reminds us of Holy Week. It is Holy Week. The

Transposition, 1 | 2011 
importance is in the smell, since for Holy Week there is what is seen, what is heard and what is smelt. They are three very important things... and, of course, what is done. There are the smells, the chant, the silence, and also the sepulchre, the Christ, the Virgin Mary: it is all the festival; liturgical theatricality.

51 This is why, when he recalls the current way of arranging the Christ on the ground in the Ceremony of Holy Wednesday, he himself decided not two decades ago, with the justification that the old sepulchre that was made up on that day in the oratory was simply adapted, but without the grand curtains and staginess that can be seen in the old photos. He took elements from what was done in each church and chapel of Calvi regarding the rituality that suited the brotherhood at the time. Similarly, he explains that the multipart response that is done today in the Lamentatio came from small improvisations by the brotherhood members themselves. Since before it was only monodic. Therefore, we see how the rhetoric of the ritual is in a process of transformation, and the very actors themselves are aware that they are adjusting deliberately and willingly - to the objectives of the act.

What, then, is the "rhetorical" development of each of the meanings in the Ceremony of Holy Wednesday in Calvi?

The easiest to perceive is the sight. The act begins at sunset approximately (according to the change of time each year, at 6 or 7 p.m.). The visual element shows the climax of the entrance of darkness, with the amplification of the same decreasing process that can be seen through the windows of the oratory. Without the use of electric light, during the act the candles are extinguished in a regulatory way at the end of each psalm to finally enter into darkness when the final candle is put out. The outside view, therefore, is gradually eliminated to begin to feel differently. It is an important alteration of individual sensation, but also a joint feeling with peers and within the very space of the oratory. With the progressive elimination of the sight, hearing and smell take on much greater importance. ${ }^{10}$ The meaning in contemporary society, which has oversized sight (Serrano 2009), of a collective act where the sight is gradually eliminated, compared to the excess and intensity of visual information and interactions that we are so accustomed to, should be evaluated. It is currently very unusual for someone in Europe to move around in the darkness, or at night along a path (and almost unthinkable in a town or city). At least we can hypothesise that with the darkness the social and individual space is radically transformed, and probably becomes more intimate and closer.

The oratory gives off a smell of wax and rosemary. The recently picked plant fills the nave with a special smell of that time of the year, of the coming spring, and of the exact place, of the oratory. The sense of smell, then, also introduces us into a very singular setting. At the same time, the movement of the brotherhood members builds this space in an olfactory way according to the corporal arrangement. First they sing the psalms and the lessons relatively separated from the bed of rosemary of the reclining Christ. In the Benedictus they are upright in a semicircle around the Christ and the rosemary, in a real physical contact between the brotherhood members. In the final moment, 0 mio Signore amato, they chant in this position but kneeling over the space of the Christ. The tucked-in position of the body and the great closeness of the rosemary make them go even further into this "feeling and expressing together" that they gradually build up. We should also investigate the contribution of the tense respiration of the painful chant that they intone together, with the body curved and with little capacity for air, added to the penetrating aroma of the rosemary. The sensation of the body itself and the chant itself - starting by 
oxygenation - is notably altered, if we compare it with a relaxed and everyday situation. Thus, in this last chant of contrition and pain, a very clearly oriented vectorialisation is built where at least four of the five senses are involved. The sight has been progressively decreased until practically the darkness; the sense of smell (and very much linked to taste) has been intensified in a staggered way until the moment of chanting breathing over the rosemary; the physical contact between the brotherhood members is now direct; and in the previous part we have described how the sonorous density has also been intensified in stages. It is the entire body of every cantore that has physically and theatrically intervened in order to construct their individual and social place through the rhetoric of the senses. And just after this moment comes the deafening row of the rattles.

The main element, however, as we have argued, is the expression of the voices (not "musical" in the academic sense, but of the voices; without any form of instrument or sonorous artefact except for the final rattles). In some way, the voices create the reverse path of the entrance into darkness (and, therefore, a path of intensification very similar to the olfactory). As we have mentioned, the chant gradually becomes unified and in stages constructs the density of the group. This is done, on the one hand, with the increase of polyphonic resources and inciting the harmonics in a timbric way; and on the other hand, with the strengthening of the intensity and with the use of more individual movements and expressions. The space is increasingly occupied by a sonorous thickness that enwraps the senses more, a heterophony that makes not only the ears vibrate a lot, but also the bodies, with an intense feeling of plenitude and of forming part of the group. The social group comes to exist due to this sonorous existence in which each person participates physically. And the sound heads the synaesthesia that reaches all the bodies and the whole space. When the emotive intensity reaches its zenith with the very chant of Holy Week, the next step is, in some way, the dislocation of the group of voices: the din of the rattles that deafen the darkness and deeply stir the bodies, leaving a deep track. The rite of passage has been accomplished, and the silence that follows places the brotherhood on the other side of the entrance doorway to the new temporary and emotive space: to Holy Week. The chant and the sound (along with the darkness and the smell) organise this sensitive transformation, individual yet collective. Thus the group remains formed for the intense Holy week that it augers in.

This corporal rhetoric is made even more apparent in a granitula (which means sea snail), the most special moment of the Good Friday procession in Calvi. The two lines of the procession intertwine in a spiral at specific points to create a human cluster of brotherhood members and penitents. They become all pressed together, bodies against bodies, along with the Dolorosa, the reclining Christ and the crosses, without space to move, but without stopping chanting in a strong voice. At this moment the bodily contact and the sound is at its maximum. And it is at this highly emotive moment for all the brotherhood members, the grand physical metaphor of their union (at the same time it is also an appreciated tourist attraction). Some years, the priest is completely encircled by the brotherhood members, in a ritual practice that, as we understand it, also leaves a track in personal relations. Direct physical contact, intense sonorous expression. When the prior gives the sign, the snail is slowly taken apart and without stopping chanting, so that the procession continues along the planned route.

57 In all these situations the chant - the words and the corresponding ritualised uttering forms the backbone of the celebration. The chant is probably the focus and decisive element, but does not act independently from the other senses. The analysis of the 
situation tells us that the chant (and the polyphonic procedures only as one of the diverse aspects of the chant) must be understood and analysed along with the sight, the sense of smell, touch and taste. The rhetoric of the senses as a whole has a very precise direction: to make the individual enter into the logic of the special time that Holy Week must be within the group of the brotherhood. On the one hand, it is done through the sensitive construction of the group, in the experience that each individual will have of the cohesion of the group, establishing shared links - which we can qualify as affective between the participants; and on the other hand, the action enables the individual arrangement of the bodies and the emotions to be framed and controlled. And this they do in the selfsame space of the oratory, among close friends, in order to prepare the intense outdoor action for the whole town that they will do in the following days. It is, therefore, a key moment in the construction of the identity of the group, in other words, a moment when each one sensitively experiences - corporally - the conviction of forming part of the community. The body is the actor of this rhetoric of the senses which unfolds within a precise passage of time and space, within a social and emotional geography that occupies and arranges the streets, temples and other spaces of the town of Calvi.

\section{BIBLIOGRAPHY}

ASENSIO, Juan Carlos, El canto gregoriano. Historia, liturgia, formas... , Madrid, Alianza editorial, 2003.

AYATS, Jaume, Les chants traditionnels des pays catalans, Toulouse, Isatis-Centre occitan des musiques et danses traditionnelles, 2007.

AYATS, Jaume ; MARTÍNEZ, Sílvia, “Singing in Processions and Festivities: A Look at Different Models of Multipart Singing in Spain”, in AHMEDAJA, Ardian ; HAID, Gerlinde (ed.), Europea Voices I. Multipart Singing in the Balkans and the Mediterranean, Vienna-Cologne-Weimar, Böhlau Verlag, 2008, p. 39-54.

AYATS, Jaume ; MARTÍNEZ, Sílvia, "Vespers in the Pyrenees: From Terminology to Reconstructing the Aesthetic Ideal of the Song”, in AHMEDAJA, Ardian ; HAID, Gerlinde (ed.), Europea Voices II, Vienna-Cologne-Weimar, Böhlau Verlag, 2010 (in press)

AYATS, Jaume ; COSTAL, Anna ; GAYETE, Iris, Cantadors del Pallars. Cants religiosos de tradició oral al Pirineu. Religious Chants of the Oral Tradition in the Pyrenees, Barcelona, Rafael Dalmau Editor, 2010.

BRUNET, Serge, La vie, la mort, la foi dans les Pyrénées centrales sous l'Ancien Régime, Val d'Aran et diocèse de Comminges : les prêtres des montagnes, Aspet, PyréGraph, 2001.

CASTÉRET, Jean-Jacques, “Mainland France Multipart Singing: Of Men and Patterns”, in AHMEDAJA, Ardian ; HAID, Gerlinde (ed.), Europea Voices I. Multipart Singing in the Balkans and the Mediterranean, Vienna-Cologne-Weimar, Böhlau Verlag, 2008.

CHARLES-DOMINIQUE, LUc ; CLER, Jérôme, La vocalité dans les pays d'Europe méridionale et dans le bassin méditérranéen., Actes du colloque deLa Napoule (06), 2 et 3 mars 2000, Villeurbanne, Modal, 2002. FERRARI, Boris, Rito e música. la Settimana Santa a Calvi (Corsica), Tesi di Laurea, MACCHIARELLA, Ignazio (thesis supervisor), Università degli Studi di Trento, 2003. 
GOFFRE, Annie [et alii], Polyphonies corses. L'orgue et la voix, Paris, L'Harmattan, 1996.

LORTAT-JACOB, Bernard, Chants de Passion. Au coeur d'une confrérie de Sardaigne, Paris, Éditions du Cerf, 1998.

MACCHIARELLA, Ignazio, "La ri/construzione della memoria musicale. Polifonie confraternali in alta Corsica”, in Lares. Rivista trimestrale di studi demo-etno-antropologici, No. 3, LXIX, 2005 ;

MACCHIARELLA, Ignazio, "Harmonizing on the Islands: Overview of Multipart Singing by Chording in Sardinia, Corsica, and Sicily”, in AHMEDAJA, Ardian ; HAID, Gerlinde (ed.), Europea Voices I. Multipart Singing in the Balkans and the Mediterranean, Vienna-Cologne-Weimar, Böhlau Verlag, 2008.

MACCHIARELLA, Ignazio, Cantare a cuncordu. Uno studio a più voci, Udine, Nota editore, Geos CD Book 634, 2009.

MACCHIARELLA, Ignazio (ed.), Tre voci per pensare il mondo. Pratiche polifoniche confraternali in alta Corsica, Udine, Nota, 2010.

PÉRÈS, Marcel ; CHEYRONNAUD, Jacques, Les voix du plain-chant, Paris, Desclée de Brouwer. [+ CD], 2001.

SERRANO, Sebastià, La festa dels sentits, Barcelona, Ara Llibres/Now, 2009.

TURNER, Victor, The Ritual Process. Structure and Anti-Structure, London, Routledge and Kegan Paul, 1969.

VIOLANT i SIMORRA, Ramon, La Setmana Santa al Pallars i al Ribagorça, Tremp, Garsineu, 1992 (1st ed. Barcelona, Barcino, 1952).

\section{NOTES}

1. The oratory of the brotherhood is private and hosts the religious acts and meetings of the members. Its exterior appearance has not changed much since the 16th century, but its interior has. Today there is no longer the row of seats that ran its rectangular perimeter, the floor has been raised slightly and the roof, since the second half of the 19 th century, has been covered by a false vault supported over columns of hollow plaster.

2. In the liturgical calendar, the three holy days (Wednesday, Thursday and Good Friday) would correspond to the Matins and Lauds, the application of which was concentrated into a single act.

3. The sisters are a small group of elderly women who collaborate on the preparation of the prayer spots (the different chapels and churches where the acts of the male brotherhoods are carried out) and attend all the acts of the male brotherhoods. During the Matins and Lauds some pray the rosary and, on the days in honour of the dead, they add to the answers of the litanies. Other moments that they value in a special way are the preparation of the three different dresses of the Virgin Mary and the mortuary bed of Christ, enwrapped in flowers. The sisters do these two rituals privately, with diverse symbolic and belief-based elements, and are focused mainly on the days of Holy Week.

4. In the dramatised reading of this moment that takes place in the Ceremony of Good Friday, after mentioning the earthquake there are a few moments of silence and withdrawal to meditate, before continuing with the evangelical narration.

5. We do not deal with the great importance that dance had. 
6. In Pyrenean churches the choir is situated at a higher level or first floor built over the main entrance, in the part facing the altar. The choir is built with wood and turned railings that open out to the nave.

7. In Catalan, the term cantador is clearly differentiated from the word cantant (which refers to a singer of a more professional kind - opera singer, pop singer, etc.) and cantaire (usually applicable to members of a choir).

8. Cantore (cantori in plural) is the word that the prior of the brotherhood of Sant'Antone uses to call the brotherhood members into the chanting, compared to the word cantatore which is used for professional singers. See the quote by Petru Bertoni below.

9. Taking into account the effect of the octave that the acoustics of the oratory already causes, plus the strengthened harmonics due to the coinciding of the voices, we have rehearsed a symbolic notation of the effect of each of the four main chords, but with the advice that the tuning of the harmonics does not correspond to the tuning of the European tempered scale or to the scale called "natural" exactly. The intention of this notation does not aim to go further than pointing out the richness of sonorous power that the chant allows, with an intense sensation of vibration of the ears and fullness of the bodies. In the upper pentagram, only of harmonics, we have emphasised the part which, to our understanding, appears most strengthened: in short the more high-pitched voice strengthens the higher octave, but with the important detail that in the final chord it strengthens the fifth of the chord, that no-one chants but which can be heard. At the same time, the effect of the sound noted as si3 is also the fourth harmonic of the basic low (a si of lower toning, therefore), and the second harmonic of the higher voice. Perhaps here the higher voice is conditioned by the harmonic and, therefore, makes the third major "channelling" that we have mentioned when speaking about the psalms.

10. We could link this sensation with acousmatics, where the sight is eliminated to give relief to the central message, sound.

\section{ABSTRACTS}

Chanted polyphony sets a communicative situation including more elements than the simple chant. This article aims to tackle the study of religious polyphonies as well as the analysis of other elements of perception taking part in it. The arrangements of bodies in space, the modulation of light, and the senses of smell and touch allow us to understand what resources are deployed to achieve an individual experience of the senses and the body, enabling the - even fictitious - feeling of belonging to a social group.

It is the beginning of a "rhetoric of the senses" that develops into highly coded ritual frameworks.

The studies of the Ceremony of Tenebrae on Holy Wednesday carried out by the brotherhood of Sant'Antone from the town of Calvi, and of the Ceremony of Vespers in the Catalan Pyrenees show us, on the one hand, the sensitive elaboration orientated by the ritual logic and, on the other hand, make us understand the aesthetical and social target of polyphonies, of the 
"sonorous density" which shapes itself as a mesh of very singular timbres, ornamentations, intensities, voices and individualities.

Thus a rhetoric of the senses and corporality unfolds, where chanted polyphony becomes a decisive matter in achieving the target: building the communitas and giving individuals access to a special time.

La polyphonie chantée instaure une situation communicative qui comprend plus d'éléments que le simple chant. Cet article propose d'aborder l'étude des polyphonies religieuses ainsi que l'analyse des autres éléments de perception qui y participent. La disposition des corps dans l'espace, la modulation de la lumière, l'odorat, le toucher, nous permettent de comprendre quelles sont les ressources mises en place en vue d'une expérimentation individuelle, sensible et corporelle, permettant l'adhésion, même fictive, à un groupe social.

C'est le début d'une « rhétorique des sens » qui se développe dans des cadres rituels bien codifiés. Les études de l'office des Ténèbres du mercredi Saint célébré par la confrérie de Sant'Antone de la ville de Calvi, et de l'office des Vêpres dans les Pyrénées catalanes, nous permettent d'observer, d'un côté, l'élaboration sensitive orientée par la logique rituelle, et, de l'autre, nous font comprendre l'objectif esthétique et social des polyphonies, de la «densité sonore » qui se construit comme un tissu de timbres, d'ornementations, d'intensités, de voix et d'individualités bien singularisées.

Il se développe alors une rhétorique des sens et de la corporalité, la polyphonie chantée détenant un rôle décisif dans le processus qui vise à bâtir la communitas et à faire en sorte que l'individu accède à un temps particulier.

\section{INDEX}

Keywords: religious chants, confraternali, corporeality and gender, ceremony of Tenebrae, orality, polyphony, psalm, Catalan Pyrenees, rhetoric of senses, Vespers, Calvi, fauxbourdon Mots-clés: chants religieux, confrérie, corporalité et genre, office de Ténèbres, oralité, polyphonie, psaume, Pyrénées catalanes, rhétorique des sens, Vêpres, Calvi, faux-bourdon

\section{AUTHORS}

\section{JAUME AYATS}

Jaume Ayats a étudié à l'École des Hautes Études en Sciences Sociales de Paris et est actuellement professeur et directeur de recherches à l'Universitat Autònoma de Barcelone. Il a conduit des recherches sur la profération collective ainsi que sur les diverses manières et situations du chant de la Méditerranée occidentale (Catalogne, Mallorca, Corse). Il a publié Córrer la sardana : balls, joves $i$ conflictes (avec Joaquim Rabaseda, 2006), Les chants traditionnels des pays catalans (2007), Cantar a la fábrica, cantar al coro (2008) et Cantadors del Pallars : Religious Chants of the Oral Tradition in the Pyrenees (avec Anna Costal et Iris Gayete, 2010). Il fait partie du groupe de recherche de l'Universitat Autònoma de Barcelona Les músiques en les societats contemporànies (MUSC).

\section{ANNA COSTAL}

Anna Costal enseigne à l'Escola Superior de Música de Catalunya (conservatoire national) et participe au groupe de recherche de l'Universitat Autònoma de Barcelona Les músiques en les societats contemporànies (MUSC). 


\section{IRIS GAYETE}

Iris Gayete est doctorante à l'Universitat Autònoma de Barcelone (UAB), travaille sur les polyphonies de la Méditerranée et participe au groupe de recherche de l'UAB Les músiques en les societats contemporànies (MUSC).

JOAQUIM RABASEDA

Joaquim Rabaseda enseigne à l'Escola Superior de Música de Catalunya (conservatoire national) et participe au groupe de recherche de l'Universitat Autònoma de Barcelona Les músiques en les societats contemporànies (MUSC). 